\title{
HAZARD ASSESSMENT, COMPREHENSIVE HYGIENIC STANDARTISATION OF FLORPYRAUXIFEN-BENZYL AND SUBSTANTIATION OF SAFETY REGULATIONS OF ITS HERBICIDE PRODUCT APPLICATION FOR RICE PROTECTION
}

\author{
O. Kravchuk, S. Serheiev, V. Medvediev, A. Hrynko, N. Kolontaieva, \\ O. Vasetska, O. Bagatska, O. Kuznetsova, P. Aleinov \\ L.I. Medved's Research Centre of Preventive Toxicology, Food and Chemical Safety, \\ Ministry of Health, Ukraine (State Enterprise), Kyiv, Ukraine
}

\begin{abstract}
Florpyrauxifen-benzyl is a novel synthetic selective leaf herbicide of the pyridine group with an auxin mechanism of action. The drug Divixton EC (a.i. - florpyrauxifen-benzyl, $25 \mathrm{~g} / \mathrm{l}$ ) is suggestedfor protection of rice crops from weeds.

For the state registration for agricultural use in Ukraine and to prevention of toxic impact on human health and quality of environment, risk assessment of the new plant protection product was conducted, and the safety criteria for human health and the environment were substantiated. The allowable daily dose of florpyrauxifen-benzyl for humans at the level of $0.02 \mathrm{mg} / \mathrm{kg}$ was substantiated; the hygienic standards for florpyrauxifen-benzyl in rice, working environment, air, water and soil, criteria for the control of the exposureon on workers, regulations for safe use of herbicide Divixton EC in agriculture have been developed.

Objective. Toxicological and hygienic assessment of florpyrauxifen-benzyl and Divixton EC drug, substantiationof safety criteria for human health, assessment of the potential impact of florpyrauxifen-benzyl on agricultural workers and the population in case of ground and aerial spraying of the preparation for the protection of rice crops.

Methods. Expert-analytical, toxicological, physical, chemical, statistical and hygienic.

Results. Based on the parameters of acute toxicity for different routes of exposure, sensitizing properties and irritative effects on the mucous membranes of the eyes and the skin, florpyrauxifen-benzyl and herbicide Divixton EC are classified as moderately hazardous (category 3). Long-term effects (carcinogenicity, mutagenicity and teratogenicity, toxicity for the reproductive function and development) are not limiting criteria for the assessment of florpyrauxifen-benzyl hazard. Approved in Ukraine allowable of florpyrauxifen-benzyl for humans is $0.02 \mathrm{mg} / \mathrm{kg}$.

As a result of field tests conducted in Ukraine, it was found that the value of occupational risk due to inhalation and through the skin in the course of ground and aerial application of florpyrauxifen-benzyl did not exceed the accepted level, sanitary protection zones ensure the safety of herbicide application for the population and environmental objects; no residues of florpyrauxifen-benzyl were detected during the harvesting of in rice grain and rice paddy.

Conclusion. Application of herbicide Divixton EC for rice protectionin accordance with agricultural and hygiene rules and regulations will not result in contamination of agricultural products and environmental objects and will be safe for population and agricultural workers.

Key Words: herbicide, florpyrauxifen-benzyl, toxicological characteristics, hazard assessment, hygiene standards and regulations.
\end{abstract}

Introduction. Florpyrauxifen-benzyl is a synthetic selective leaf herbicide of the pyridine group with an auxin mechanism of action. On its basis the drug Divixton EC (a.i. - florpyrauxifen-benzyl, $25 \mathrm{~g} / \mathrm{l}$ ) is suggested for use in Ukraine to protect rice crops from the most common yearling broadleaf and grass weeds with a consumption rate $1.0-1.21$ /ha single, twofold application, by ground and aerial spraying methods.

Florpyrauxifen-benzyl is registered in the USA (2017). The inclusion of this active substance in Annex I of the EU Regulation $1107 / 2009$ is officially approved and became effective as of 24 July 2019 [1].
Florpyrauxifen-benzyl is a new active substance of the drug that has not been previously registered in Ukraine. A key element of this procedure is the assessment of the dangers of a new plant protection product, the substantiation of safety criteria and requirements, the observance of which will prevent potential negative effects on human health and environmental quality change.

The Objective of the Research was to evaluate the danger of florpyrauxifen-benzyl and Divixton EC drug for humans and the environment;substantiate daily allowable dose (DAD) of florpyrauxifen-benzyl for humans, its hygienic standards in the rice, in the work- 
ing zone air, ambient air, water and soil, as well as criteria for controlling the integrated effects on workers, safety requirements for the use of the drug, the timeframe for resuming work and the waiting time to harvest rice after the application of the herbicide.

Methods and Materials.Florpyrauxifenbenzyl chemical structure is related to derivatives of picolinic acid. The chemical name, structural formula and physical and chemical characteristics of florpyrauxifen-benzyl are given in Table 1.

Toxicological and hygienic assessment of the Divixton EC drug and its active substance florpyrauxifen-benzyl, substantiation of DAD of florpyrauxifen-benzyl was performed according to the results of studies conducted by the manufacturer and given in the references [1-6] according to the Guidelines [8] and Sanitary classification applied in Ukraine [9]. The study of the dynamics of the content of florpyrauxifen-benzyl and the justification of its maximum permissible level (MPL) in rice was carried out in accordance with the Guidelines [8] and basic principles laid down in the Guidelines of the United Nations Food and Agriculture Organization (FAO) [10]. Samples were collected and transported for research in accordance with Standardized rules [11].

The content of florpyrauxifen-benzyl in rice was determined in accordance with the

Physical and chemical properties of florpyrauxifen-benzyl

Table 1

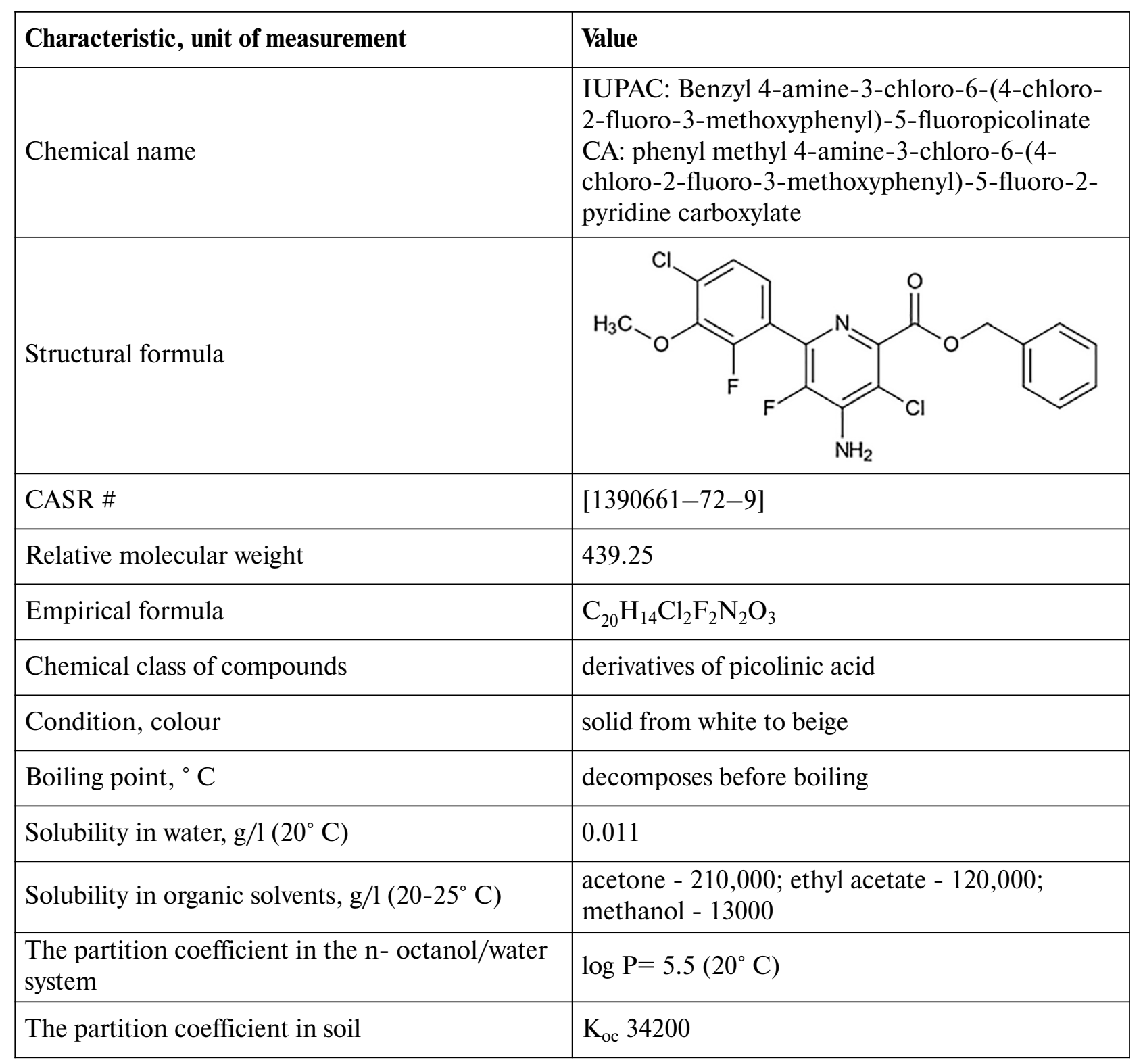


requirements of the Guidelines [12]. The limit of quantification (QL) by high performance liquid chromatography (HPLC) in rice grains is $0.005 \mathrm{mg} / \mathrm{kg}$.

In order to substantiate the approximate limit values of exposure (ALV) of florpyrauxifen-benzyl in the working zone air and ambient air Guidelines [13 - 15] were applied.

The development and justification of the maximum permissible concentration (MPC) of florpyrauxifen-benzyl in water basins was carried out according to the Guidelines [8] and basic Guidelines [16, 17]. According to the developed Guidelines for the determination of florpyrauxifen-benzyl in water basins [18], limit of quantification (QL) of a substance by the method of high-performance liquid chromatography (HPLC) is $0.001 \mathrm{mg} / \mathrm{dm} 3$.

Substantiation of the approximate permitted concentration (APC) of florpyrauxifenbenzyl in soil was carried out according to Guidelines [19]. QL of florpyrauxifen-benzyl in soil by HPLC method according to the developed Guidelines [20] is $0.05 \mathrm{mg} / \mathrm{kg}$.

To predict the danger of exposure to florpyrauxifen-benzyl for agricultural workers during its application selective effect coefficients (SEC) were calculated as the ratio of effective application rate and the values of average lethal dose when applying a substance to the skin (SECd) and concentrations of inhalation exposure (SECi). The results were evaluated on the following scale: SEC $<1-$ extremely low selective effect, SEC 1 to $99-$ low selective action, SEC $\geq 100$ - sufficient selective effect [21].

Study and assessment of the danger of external influence of florpyrauxifen-benzyl on agricultural workers engaged in the application of the Divixton EC drug, of the potential impact of florpyrauxifen-benzyl on the population outside the sanitary-protective zone during the application of the drug and on those working in the treated fields were conducted in accordance with the methods suggested in the Guidelines [8, 22].

According to the Guidelines [22] for the substantiation of an estimated allowable inhalation dose (ADi) the ALV in the air of working zone was applied; when substantiating the estimated allowable dermal dose (ADd) we used NOAEL for rats with reproductive (systemic) toxicity, maximum absorption value of florpyrauxifen-benzyl through the skin, calcu- lated oral-skin coefficient and isoeffective NOAEL for skin application and an assurance coefficient.

The determination of the content of florpyrauxifen-benzyl in industrial and environmental facilities was carried out in accordance with the requirements specified in the Guidelines [23]. The limits of quantification (QL) of the active substance by HPLC method in the air of the working area is $0,07 \mathrm{mg} / \mathrm{m} 3$, atmospheric air $-0,008 \mathrm{mg} / \mathrm{m} 3$ and soil $0,14 \mathrm{mg} / \mathrm{kg}$.

Results and Discussion. According to the Hygiene classification of pesticides by hazard level (State sanitary rules 8.8.1.002-98) [9] technical florpyrauxifen-benzyl is referred to the 4th hazard category as for acute oral and dermal toxicity parameters, acute inhalation toxicity to the 3rd hazard category, for irritative effect on the skin - to the 4th hazard category and on the mucous membranes of the eyes - to the 3rd hazard category, allergenic action - to the 3rd hazard category. By limiting toxicity indicators florpyrauxifen-benzyl is referred to pesticides of the 3rd hazard category.

According to State sanitary rules 8.8.1.00298 [9] Divixton EC is referred to the 4th hazard category as for acute oral and dermal toxicity parameters, as for acute inhalation toxicity - to the 3rd hazard category for irritative effect on the skin and mucous membranes of the eyes to the 3rd hazard category, allergenic action to the 3rd hazard category. By limiting toxicity indicators Divixton EC is referred to the 4th hazard category.

In the study of absorption, metabolism and excretion of radiolabelled florpyrauxifen-benzyl $(14 \mathrm{C})$ it was found that the substance is rapidly absorbed, excretion is $74-90 \%$ (in rats), $83-87 \%$ (in mice) and $93 \%$ (in rabbits). The absorbed dose is rapidly excreted in the urine: total elimination is $11-15 \%, 37-48 \%$, and $67 \%$ of the administered dose in rats, mice and rabbits, respectively. Most of the substance excreted in the urine (90-92\%) falls within the first 24 hours after administration to rodents and 96\% occurs during the first 48 hours in rabbits. The rest of the oral dose was excreted in the faeces: $59-77 \%$ in rats, $39-46 \%$ in mice and $25 \%$ in rabbits.

In urine, blood, and liver samples florpyrauxifen-benzyl was not detected. In urine, the most significant metabolite for all animal species was florpyrauxifen acid. Other metabo- 


\section{ORIGINAL RESEARCH \\ TOXICOLOGY OF PESTICIDES}

lites identified as O-dimethyl glucuronide florpyrauxifen, O-dimethyl sulphate florpyrauxifen and $\mathrm{O}$-dimethyl florpyrauxifen accounted for $<3 \%$ of the administered dose in rats and mice and $8-17 \%$ of the dose in rabbits. In general, florpyrauxifen-benzyl is rapidly absorbed. The absorbed fraction undergoes complete hydrolysis to the acid and other less relevant metabolites that are rapidly eliminated from the body.

Accumulation in the tissues was not detected. No significant sex differences in the distribution of the substance in the animal body have been established.

A comparative study of the metabolism of florpyrauxifen- benzyl in vitro in the microsomes of the liver of mice, rats, rabbits, dogs, and human donors revealed the similarity of its metabolic profile for different species.

An in vitro skin absorption study showed that florpyrauxifen-benzyl has a low dermal absorption property $-0.07 \%$ of the undiluted substance dose and $4.4 \%$ of the diluted substance (1: 1000).

For florpyrauxifen-benzyl with subacute dermal intakes for rats males and females NOAEL is at $1000 \mathrm{mg} / \mathrm{kg}$ (based on systemic toxicity), with subacute oral admission NOAEL for rats males and females is $<250 \mathrm{mg} / \mathrm{kg}$ (based on increase in the absolute mass of the thyroid gland and kidneys), NOEL for mice males and females is $1000 \mathrm{mg} / \mathrm{kg}$, NOAEL for dogs $30000 \mathrm{ppm}$ (for males $-873 \mathrm{mg} / \mathrm{kg}$ and for females - $1035 \mathrm{mg} / \mathrm{kg}$ ).

In subchronic experiments NOAEL for male rats is $1000 \mathrm{mg} / \mathrm{kg}$, for female rats is $100 \mathrm{mg} / \mathrm{kg}$ (based on the increase of urine $\mathrm{pH}$ and weak mineralization of kidneys tubular medulla in females), NOEL for male mice is $1000 \mathrm{mg} / \mathrm{kg}$, NOAEL for female mice is $1000 \mathrm{mg} / \mathrm{kg}$ (based on weight loss, absolute and relative weight of ovaries in females ); in dogs at the researched doses toxic effects were not detected, NOEL for dogs is $30000 \mathrm{ppm}$ (for males $-1008 \mathrm{mg} / \mathrm{kg}$ and females $-1216 \mathrm{mg} / \mathrm{kg}$ ).

In chronic oral exposure NOAEL for rats in males and females is $10 \mathrm{mg} / \mathrm{kg}$ (in males on the basis of the absolute mass of epididymis increase, increase in the number of cases of weak/moderate degree of testicular degeneration; in females - increase in the absolute mass of the kidneys, decrease in diuresis and increase of specific urine mass, decrease of absolute and/or relative weight of spleen, increase of absolute weight of adrenal glands). NOAEL for mice in males is $1000 \mathrm{mg} / \mathrm{kg}$, females $-800 \mathrm{mg} / \mathrm{kg}$ (for systemic toxicity). NOAEL for dogs is $300 \mathrm{ppm}$ (males $-7.4 \mathrm{mg} / \mathrm{kg}$, females $-7.3 \mathrm{mg} / \mathrm{kg}$ ) on the basis of the increase in cases of focal epithelial hyperplasia pelvises of the kidneys.

Florpyrauxifen-benzyl does not show mutagenic activity. Carcinogenic effects were not detected in mice experiment. Male rats showed an increase in cases of breast fibro adenomas and unilateral testicular adenoma of the testes; no carcinogenic effect was detected in females. NOAEL as for oncogenic effect for male rats is $50 \mathrm{mg} / \mathrm{kg}$.

NOAEL for pregnant female rats is 975$1000 \mathrm{mg} / \mathrm{kg}$, for foetal development is less than $975-1000 \mathrm{mg} / \mathrm{kg}$ (based on the presence of developmental abnormalities in 3 foetuses per litter). NOEL for pregnant female rabbits is less than $1042 \mathrm{mg} / \mathrm{kg}$ (due to weight loss); NOAEL for foetal development is $1042 \mathrm{mg} / \mathrm{kg}$.

NOAEL as for reproductive toxicity is $300 \mathrm{mg} / \mathrm{kg}$, NOAEL as for systemic toxicity is less than $10 \mathrm{mg} / \mathrm{kg}$ (based on significant increase in kidney mass in P1 females, increase in size of kidney pelvis, morphological changes of internal organs).

According to the State sanitary rules 8.8.1.002-98 florpyrauxifen-benzyl as for mutagenic activity is referred to the 4th hazard category, carcinogenic activity - 3rd hazard category, teratogenic activity, embryo and reproductive toxicity - 3rd hazard category.

Thus, florpyrauxifen-benzyl is characterized by a general toxic effect on the body with predominant renal damage.

Based on the NOAEL limit for rats of $10 \mathrm{mg} / \mathrm{kg}$ and an assurance coefficient of 100 , the daily allowable dose (DAD) of florpyrauxifen-benzyl in humans is $0.1 \mathrm{mg} / \mathrm{kg}$. However, the substance belongs to synthetic auxin herbicides, which in plants imitate the effect of natural plant hormone auxin, the effect of florpyrauxifen-benzyl in warm-blooded animals is characterized by the absence of a clear "doseresponse"dependence, displays or increase of toxicity at low doses, the inability to completely eliminate the hormonal mechanism of tumour development, toxic effects on posterity in the postnatal period of development. In this regard, while reasoning the DAD a modifying factor of 5 was introduced. Given the above negative characteristics of DAD, florpyraux- 


\section{ORIGINAL RESEARCH}

TOXICOLOGY OF PESTICIDES

ifen-benzyl in humans is recommended and approved in Ukraine at the level of $0.02 \mathrm{mg} / \mathrm{kg}$.

Based on the hygienic assessment of stability, migration, accumulation, decomposition of florpyrauxifen-benzyl in the environment and raw food, study standards and regulations for safe use of the drug Divixton EC (a.i. florpyrauxifen -benzyl, $25 \mathrm{~g} / \mathrm{l}$ ) the following results were obtained.

Low vapour pressure of florpyrauxifen-benzyl (3.2410-02 $\mathrm{MPa}$ at $20^{\circ} \mathrm{C}$ ) together with a low Henry's law constant (1.28 PA m3/mol at $\mathrm{pH} 7$ ) and a calculated half-life in photochemical oxidation in air ( 1 or 2 days) indicate that the levels of florpyrauxifen-benzyl in the air after regular application will be very low.

Due to low evaporation potential and the physicochemical properties of florpyrauxifenbenzyl, the concentrations in the air and their transfer to the air are considered negligible.

A study of ALV variables of florpyrauxifenbenzyl in work zone areas and for the ambient air of populated places [8, 13-15] was conducted. To calculate the ALV of florpyrauxifenbenzyl the parameters of its acute toxicity when administered orally, dermally and inhaled, the estimated threshold concentration for animals with chronical inhalation exposure, molecular weight of substances, etc. were used. Recommended and approved ALV for florpyrauxifen-benzyl in work zone areas is $1.5 \mathrm{mg} / \mathrm{m}^{3}$ (QL by HPLC method $0.07 \mathrm{mg} / \mathrm{m}^{3}$ ), in ambient air of populated places is of $0,006 \mathrm{mg} / \mathrm{m}^{3}$ (QL by HPLC method $-0.006 \mathrm{mg} / \mathrm{m}^{3}$ ).

As florpyrauxifen-benzyl is a product used in flooded rice ponds (paddies), aerobic flooding conditions are most important in determining the degradation way of florpyrauxifenbenzyl in soil. When applied to the water layer in aerobic systems of submerged soils, florpyrauxifen-benzyl is either hydrolysed to the acid in the aqueous layer or distributed on the soil, where it decomposes to florpyrauxifen hydroxybenzyl ether. The maximum total concentrations of florpyrauxifen acid and hydroxybenzyl ether in the system were $33 \%$ and $16 \%$ of the introduced radioactivity, respectively. Both metabolites degraded further to florpyrauxifen hydroxy acids. The maximum total concentration of florpyrauxifen hydroxy acid in the system was $64 \%$ of the radioactivity introduced. The final degradation products are $\mathrm{CO}_{2}$ and non-extractable residues.
The photolytic half-life of florpyrauxifenbenzyl in soil is approximately 49.3 days of natural annual sunlight at $30-50^{\circ} \mathrm{N}$. The degradation of florpyrauxifen-benzyl in the dark control samples was very slow during the study.

The degradation of florpyrauxifen-benzyl under field conditions was studied in 6 commercial rice paddy fields in Italy and Spain. Primary degradation product - florpyrauxifen acid - was observed in rice paddy water maximum $92.8 \%$ of the starting material used, florpyrauxifen hydroxy acid $-13.1 \%$, florpyrauxifen hydroxybenzyl ether $-0.6 \%$, small amounts of two dechlorinated photo products were also observed $(<3 \%)$. In rice paddy soil only starting substance was detected in large amounts. Florpyrauxifen-benzyl rapidly degraded with an average geometric size T50, which equals to 3.3 days in rice paddy soil. In rice paddy water florpyrauxifen-benzyl and metabolite florpyrauxifen acid showed the value of average geometrical T50 for less than 1 day [3]. According to PPDB data [6] T50 degradation florpyrauxifen benzyl in soil of flooded rice paddies range is within 8-10 days, florpyrauxifen acid range is within 7-10 days.

The results of field studies allow us to attribute florpyrauxifen-benzyl and florpyrauxifen acid to the hazard class 4 as for the criterion "soil stability" (State sanitary rules 8.8.1.002-98) [8].

The GUS index calculated for florpyrauxifen-benzyl is 0.76 , indicating a low leaching potential (GUS < 1.8) from the soil, whereas for florpyrauxifen acid GUS is 3.38, i.e. the substance is characterized by a high potential leaching (GUS > 2.8) [6]. In this regard, it is expected that the starting material (florpyrauxifen-benzyl) will not leach through the soil profile and enter groundwater, which is not true for florpyrauxifen acid. But given the potential concentrations of florpyrauxifenbenzyl and the rate of decomposition of its transformation products in soil, the concentration of these products in groundwater will be very low.

The behaviour of florpyrauxifen-benzyl in water is characterized by relative resistance to hydrolysis at acidic and neutral $\mathrm{pH}$ values, but in alkaline medium florpyrauxifen-benzyl is rapidly hydrolysed to florpyrauxifen acid. The T50 values for florpyrauxifen-benzyl at $25^{\circ} \mathrm{C}$ were 913,111 , and 1.3 days at $\mathrm{pH} 4,7$, and 9 respectively. Florpyrauxifen acid was resistant to hydrolysis. 


\section{ORIGINAL RESEARCH}

\section{TOXICOLOGY OF PESTICIDES}

The photo degradation of florpyrauxifenbenzyl in sterile $\mathrm{pH} 4$ buffer and in natural water was extremely fast with T50 values of 0.07 and 0.16 days (adjusted for summer sunlight at $40^{\circ} \mathrm{N}$ ). Florpyrauxifen-benzyl rapidly photodecomposes to dechlorinated florpyrauxifen-benzyl, which is subsequently rapidly hydrolysed to dechlorinated florpyrauxifen acid. Further degradation leads to the formation of several small chain organic acids and the release of $\mathrm{CO}_{2}$.

When applied to the aqueous layer in aerobic systems water-sediment florpyrauxifenbenzyl either hydrolyses to florpyrauxifen acid in the aqueous layer or is distributed in the precipitate where it degrades to florpyrauxifen hydroxybenzyl ether. The geometric average of total T50 values in the water-sediment system had the following values: 5 days for florpyrauxifen-benzyl, 6 days for florpyrauxifen acid, 9 days for florpyrauxifen hydroxybenzyl ether, and 80 days for florpyrauxifen hydroxy acid. The final decomposition products were $\mathrm{CO}_{2}$ and non-extractable residues.

The results of studies in water-sediment aerobic systems allow us to roughly attribute florpyrauxifen-benzyl and florpyrauxifen acid to the hazard class 2 as for the criterion "soil in water" (State sanitary rules 8.8.1.002-98) [9].

Substantiation of maximum allowable concentration of florpyrauxifen-benzyl in water reservoirs of drinking and community purpose was conducted in several ways $[8,15,16]$ : the study of the impact of the active substance on the organoleptic properties of water and the overall sanitary regime of reservoirs, determination of maximum defunct concentration of florpyrauxifen-benzyl in water as for sanitarytoxicological harmfulness.

Threshold concentration as for the effect of florpyrauxifen-benzyl on the smell is the concentration of the substance at the level of $0.002 \mathrm{mg} / \mathrm{dm}^{3}$. The threshold concentration of the substance as for the effect on chromaticity and turbidity was above its concentration at the limit of solubility $\left(>0.01 \mathrm{mg} / \mathrm{dm}^{3}\right)$. The threshold concentration of the substance as for the influence on the ability of aqueous solutions to foaming is $0.009 \mathrm{mg} / \mathrm{dm}^{3}$.

Thus, the threshold concentration as for the effect on the organoleptic properties of water is the concentration of florpyrauxifen-benzyl at the level of $0.002 \mathrm{mg} / \mathrm{dm}^{3}$.
To assess the impact of florpyrauxifen-benzyl on the general sanitary regime of reservoirs the nature and intensity of biochemical oxygen demand (BOD) - the most significant indicator of the ability of the reservoir to purify itself of organic pollution; dissolved oxygen value, status of ammonization and nitrification of nitrogen-containing organic compounds, $\mathrm{pH}$ reaction of aquatic environment, dynamics of development and extinction of aquatic saprophytic microflora were studied. Studies were conducted with florpyrauxifen-benzyl at concentrations of $0.01 \mathrm{mg} / \mathrm{dm}^{3}, 0.001 \mathrm{mg} / \mathrm{dm}^{3}$ and $0.0001 \mathrm{mg} / \mathrm{dm}^{3}$ in river water.

Florpyrauxifen-benzyl at concentrations of $0.01 \mathrm{mg} / \mathrm{dm}^{3}$ and $0.001 \mathrm{mg} / \mathrm{dm}^{3}$ stimulates BOD processes. Changes of BOD in the model reservoir with a concentration of florpyrauxifen-benzyl $0.01 \mathrm{mg} / \mathrm{dm}^{3}$ in all study periods ranged up to $20 \%$ compared to the control reservoir. The concentration of florpyrauxifenbenzyl $0.01 \mathrm{mg} / \mathrm{dm}^{3}$ was taken as the threshold for influencing the BOD processes. The effect of florpyrauxifen-benzyl on the dissolved oxygen content of the reservoir water was negligible. The content of florpyrauxifen-benzyl at the level of $0.001 \mathrm{mg} / \mathrm{dm}^{3}$ was adopted as a threshold concentration due to the effects on the processes of ammonization and nitrification.

Florpyrauxifen-benzyl did not affect the $\mathrm{pH}$ of the aqueous medium. The results of microbiological studies have shown that florpyrauxifenbenzyl has no significant effect on the aquatic microflora. A concentration of $0.001 \mathrm{mg} / \mathrm{d}^{3}$ was adopted at the threshold concentration of florpyrauxifen-benzyl in order to influence the dynamics of development and extinction of aquatic saprophytic microflora.

Thus, the threshold concentration as for the effect on the general sanitary regime of reservoirs is the concentration of florpyrauxifenbenzyl at the level of $0.001 \mathrm{mg} / \mathrm{dm}^{3}$.

When calculating the maximum inactive concentration of florpyrauxifen-benzyl in water for sanitary-toxicological signs of harmfulness, we applied the value of DAD of florpyrauxifen-benzyl $0.02 \mathrm{mg} / \mathrm{kg}$, body weight $60 \mathrm{~kg}$, average daily consumption of water at the level of 31 and $10 \%$ of the allowable daily intake of the substance into the human body with water in accordance with basic provisions [17]. As a result of the calculations the value of the maximum inactive concentration of florpyrauxifen-benzyl is obtained at the level of $0.04 \mathrm{mg} / \mathrm{dm}^{3}$. 
On the basis of threshold and subthreshold levels set for the basic hazard parameters, MPC of florpyrauxifen benzyl in drinking and community purpose water reservoirs of was reasoned. Analysis of the received data allowed coming to the conclusion that the limiting indicator of the adverse effects of florpyrauxifen benzyl is a general sanitary one. As MPC of florpyrauxifen benzyl in water reservoirs of drinking and community purpose the recommended and approved concentration is $0.001 \mathrm{mg} / \mathrm{dm}^{3}$ (a general sanitary limiting harmful indicator). The limit of quantitation of florpyrauxifen-benzyl in water by HPLC method is $0.001 \mathrm{mg} / \mathrm{dm}^{3}$.

The metabolism of the active substance of florpyrauxifen-benzyl in water has been researched $[3,5]$ using three test substances with a radioactive label of 14C (on phenyl-, pyridine- and benzyl -fragments) under the conditions of three typical rice planting/application methods: application in water, with flooding and application on leaves, with application on a dry inoculation. As a result, the metabolism of florpyrauxifen-benzyl is found to be similar in animals, plants and environmental objects. The main hydrolysis products of florpyrauxifen-benzyl, which are observed in all objects, are florpyrauxifen acid and florpyrauxifen hydroxy acid.

Field tests of herbicide containing $25 \mathrm{~g} / 1$ of florpyrauxifen-benzyl included the treatment of rice shoots in flooded areas (Italy, Spain) and wet soil with subsequent flooding (Greece) at a drug consumption rate of 1.0-1.2 1/ha, 5374 days before harvest. Samples of rice grains in the husk, without husk and rice straw samples were analysed for the content of florpyrauxifen-benzyl and its main metabolites florpyrauxifen acid and florpyrauxifen hydroxy acids (HPLC method and LC/MS/MS mass spectrometry). Florpyrauxifen-benzyl, florpyrauxifen acid and florpyrauxifen hydroxy acid in the rice grain without husk were not detected. The maximum amount of florpyrauxifen-benzyl residue in rice grains in the husk was $0.065 \mathrm{mg} / \mathrm{kg}$ and in rice straw $0.139 \mathrm{mg} / \mathrm{kg}$, florpyrauxifen acid in grains in the husk $-0.005 \mathrm{mg} / \mathrm{kg}$ and in $0.054 \mathrm{mg} / \mathrm{kg}$ in straw. The residues of hydroxyacid in rice with husk were not detected, in straw were up to $0.054 \mathrm{mg} / \mathrm{kg}[3,5]$.

Field tests of herbicides containing $25 \mathrm{~g} / 1$ and $300 \mathrm{~g} / 1$ of florpyrauxifen-benzyl (Austra- lia) included spraying rice shoots and making a working solution in water at a consumption rate of 30 and $60 \mathrm{~g}$ of a.i./ha. In 5 testsconducted over the two seasons (in 2013 and 2014), residues of florpyrauxifen-benzyl and florpyrauxifen acid in the rice grain crop were not detected [2].

Herbicide Divixton EC (a.i. florpyrauxifenbenzyl, $25 \mathrm{~g} / \mathrm{l}$ ) was tested in Ukraine to protect rice at the maximum consumption rate of $1.2 \mathrm{l} / \mathrm{ha}$ ( $30 \mathrm{~g} /$ ha of florpyrauxifen-benzyl) single, twofold application by ground and aerial methods. One of the objectives of the study was to substantiate the MPL values of the content of residues of florpyrauxifen-benzyl in rice grains. For this purpose, a preliminary calculation of the safe level of the content of florpyrauxifen-benzyl in the food ration was made, based on the value of its DAD.

For the DAD of $0.02 \mathrm{mg} / \mathrm{kg}$, the allowable daily intake of florpyrauxifen-benzyl in the human body is $1.2 \mathrm{mg} /$ day. According to the principles of complex hygienic regulation, it is assumed that up to $70 \%$ of the substance, contained in all media, can enter the food ration[8]. Taking this into consideration, the estimated safe intake of florpyrauxifen-benzyl in the food ration of a human is $0.84 \mathrm{mg} /$ day.

Studies on the actual content of florpyrauxifen-benzyl in rice (varieties: Viscount and Ukraine 96) were conducted in 2016, 2017 and 2018 at three sites in Kherson region using backpack, aircraft and bar spraying methods.

According to the research results, after a single treatment in samples of green rice plants from plot 1 the initial concentration of florpyrauxifen-benzyl was $0.296 \mathrm{mg} / \mathrm{kg}$, after 7 days it decreased to $0.217 \mathrm{mg} / \mathrm{kg}$, after 14 days to $0.006 \mathrm{mg} / \mathrm{kg}$, after 28 days it did not exceed $0.005 \mathrm{mg} / \mathrm{kg}$. On the day of processing in the soil of the rice paddy, florpyrauxifenbenzyl was not detected; 2 days after treatment and flooding the paddy with water, the concentration of florpyrauxifen-benzyl in water did not reach $0.001 \mathrm{mg} / \mathrm{dm}^{3}$ (MPC in the water of reservoirs $=0.001 \mathrm{mg} / \mathrm{dm}^{3}$ ); after 7 , 14 and 28 days in the water of the paddy, as well as in the water of filling and discharge canals (from 2 to 28 days) florpyrauxifen-benzyl was not detected. In the grain yield of rice (115 days after a single treatment) and in the soil of the rice paddy, during this period, florpyrauxifen-benzyl was not detected. 


\section{ORIGINAL RESEARCH}

TOXICOLOGY OF PESTICIDES

In the grain yield of rice from plots 2 (111 days after single treatment) and 3 (104 days after twofold treatment), florpyrauxifen-benzyl was not detected.

The dynamics of the decomposition of florpyrauxifen-benzyl in rice is shown in Fig. 1.

In the EU, a maximum residue level (MRL) for florpyrauxifen-benzyl, $\mathrm{mg} / \mathrm{kg}$ in rice grain QL is $0.02 \mathrm{mg} / \mathrm{kg}$ (the sum of individual QL of florpyrauxifen-benzyl and florpyrauxifen acid).

Based on the toxicological and hygienic assessment of the drug Divixton EC and its active ingredient, the results of studies of the content of florpyrauxifen-benzyl in rice, and taking into consideration the generally accepted in hygienic standardization methodical approaches of considering the value of MRL in rice grain for the EU countries the MPL of florpyrauxifen-benzyl in rice grain is set as $0.01 \mathrm{mg} / \mathrm{kg}$ (the limit of quantitative determination by HPLC method is $0.005 \mathrm{mg} / \mathrm{kg}$ ).

According to [8] it is established that when the content of florpyrauxifen-benzyl in rice is at the level of the recommended hygienic standard, the possible daily intake of the substance into the human body with the specified product may not be more than $0,016 \%$ of the allowable daily value.

After the application of Divixton EC herbicide it is not required to set a waiting period for harvesting the rice grain.

Using the findings of field research and equations of the first order [24, 25], we calculated the constant of decay rate $(\mathrm{k})$ and halflife period $\left(\mathrm{T}_{50}\right)$ of florpyrauxifen-benzyl in rice, making it possible to assess florpyrauxifen-benzyl in terms of stability in vegetative crops and agricultural raw material according to State sanitary rules 8.8.1.002-98 (Table 2).

The calculated half-life period $\left(\mathrm{T}_{50}\right)$ is 10 days for rice. The data obtained, allow us to attribute florpyrauxifen-benzyl to the 3rd category of hazard as for stability in rice according to the Sanitary classification of pesticides as for the hazard level(State sanitary rules 8.8.1.002-98) asfor indicator "stability in vegetative crops and agricultural raw materials".

Florpyrauxifen-benzyl and its main metabolite florpyrauxifen acid in terms of "stability in soil" refers to the pesticides of $4^{\text {th }}$ category of

Table 2

Degradation rate and hazard class

\begin{tabular}{|c|c|c|c|c|c|c|}
\hline Crop & $\mathrm{y}=\mathrm{a} \beta^{\mathrm{x}}$ & $\mathrm{R}^{2}$ & $\begin{array}{c}\mathrm{k}, \\
\mathrm{day}^{-1}\end{array}$ & $\begin{array}{c}\mathrm{T}_{50} \\
\text { day }\end{array}$ & $\begin{array}{c}\mathrm{T}_{90} \\
\text { day }\end{array}$ & $\begin{array}{c}\text { hazard category } \\
\text { according to State } \\
\text { sanitary rules } \\
8.8 .1 .002-98\end{array}$ \\
\hline Rice & $\mathrm{y}=0,2711 \mathrm{e}^{-0,068}$ & 0.82 & 0.068 & 10 & 34 & 3 \\
\hline
\end{tabular}

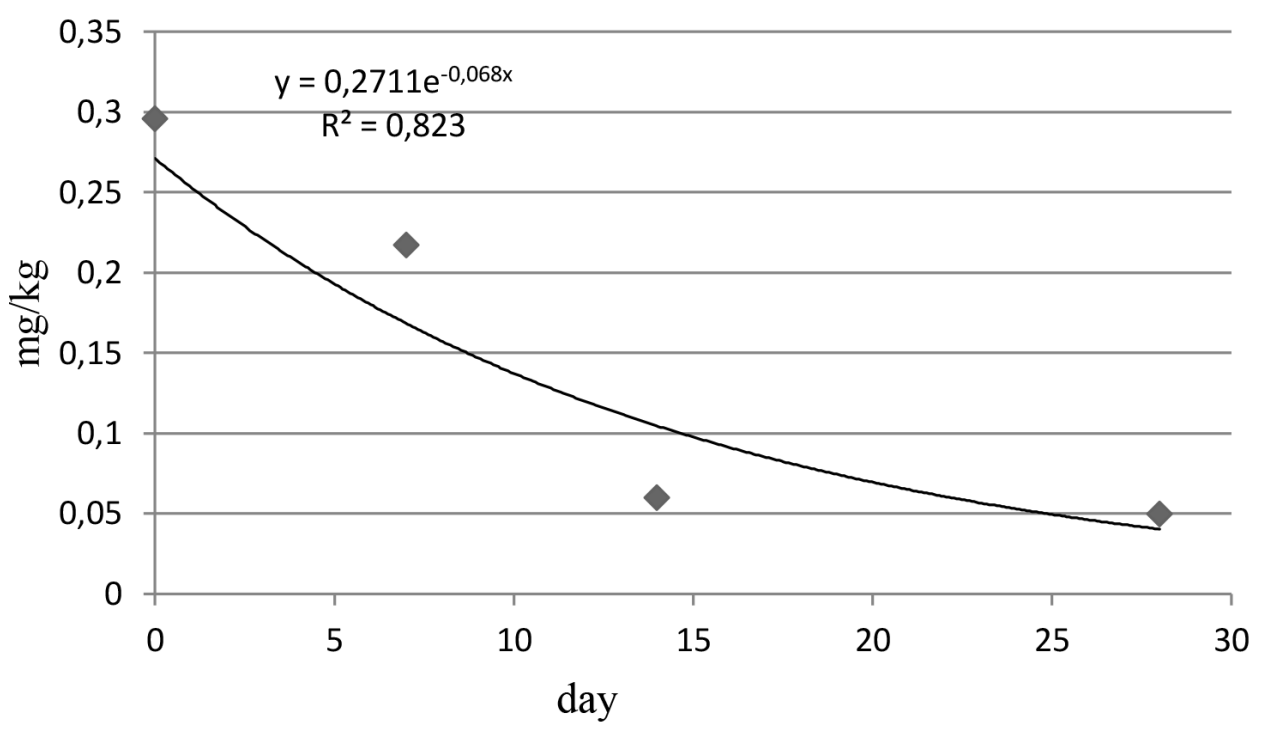

Fig. 1. Dynamics of the decomposition of florpyrauxifen-benzyl in rice 


\section{ORIGINAL RESEARCH}

TOXICOLOGY OF PESTICIDES

hazard, florpyrauxifen-benzyl is non-volatile and well absorbed in soil; florpyrauxifen acid is poorly absorbed in soil, but the high rate of biodegradation of this main metabolite does not allow its migration to groundwater. Given the above, a reasoned calculation of the value of the estimated permissible concentration of florpyrauxifen-benzyl in soil was conducted [19]. For the calculations, the MPL value of florpyrauxifen-benzyl in the rice grain was taken as $0.01 \mathrm{mg} / \mathrm{kg}$, which allows recommending the APC of florpyrauxifen-benzyl in soil at the level of $0.14 \mathrm{mg} / \mathrm{kg}$. The limit of quantification by HPLC method is $0.05 \mathrm{mg} / \mathrm{kg}$.

Preliminary assessment of the danger of exposure to florpyrauxifen-benzyl for workers engaged in its application showed that the substance has a sufficient selective effect (SECd was 10,204, SECi - 1731), the most efficient consumption rate of florpyrauxifen-benzyl is thousand times lower for average lethal doses and concentrations upon admission to the skin and through the respiratory tract.

Studies of the content of the active ingredient in the objects of production and environment and assessment of the effect of the Divixton EC drug on agricultural workers and the population during and after its use (ground bar spraying of rice with a consumption rate of $1.2 \mathrm{l} / \mathrm{ha}$ - working fluid $150 \mathrm{l} / \mathrm{ha}$, aerial spraying of rice with a consumption rate of 1.2 1/ha working fluid of $50 \mathrm{l} / \mathrm{ha}$ ) were conducted.

The results obtained showed that in the case of ground spraying in the air of the breathing zone of the tanker attendant and tractor operator, in the air of the zone of possible spray sweep at a distance of $300 \mathrm{~m}$ from the boundary of the site during the application and an hour later, as well as in the air above the site one hour and 2 days after the spraying florpyrauxifen-benzyl was not detected (detection limit (DL) of florpyrauxifen-benzyl by HPLC method in the air of the working area was $0.07 \mathrm{mg} / \mathrm{m}^{3}$ and in the air $-0.006 \mathrm{mg} / \mathrm{m}^{3}$ ); in the soil of the zone of possible sweep of the spray at a distance of $300 \mathrm{~m}$ from the boundary of the site in an hour florpyrauxifen-benzyl was also not detected.

When applying the herbicide by aerial method in the air of the breathing zone of the tanker attendant, pilot and signalman the concentration of florpyrauxifen-benzyl did not exceed the value of the hygienic standard (ALV in the air of the working zone is $1.5 \mathrm{mg} / \mathrm{m}^{3}$ ), in the air of the zone of possible sweep of the spray at a distance of $1000 \mathrm{~m}$ from the boundary of the site during spraying the concentration of florpyrauxifen-benzyl did not exceed the value of the hygienic standard (ALV in ambient air $\left.-0,006 \mathrm{mg} / \mathrm{m}^{3}\right)$; in the air of working zone over the area in an hour and 3 days after spraying the content of florpyrauxifen-benzyl was significantly below the corresponding hygienic standard; in the soil of zones of possible sweep of the spray at a distance of 1000 meters from the boundary of the site in an hour the content of florpyrauxifenbenzyl did not exceed the value of APC.

Based on the analysis of the results obtained, the production environment is sufficiently safe for workers at the stages of the application of the Divixton EC herbicide by ground and aerial methods; sanitary protection zones established for the agro-industrial sector ensure the safety of ground and aerial application of the drug for the population and objects of the environment; at the stage of crop processing the production environment is safe enough when performing mechanised works 3 days after spraying.

According to the Guidelines 8.8.1.4-1622009 [22] proven approximate allowable inhalation (AAi) and dermal (AAD) dose of florpyrauxifen-benzyl for people who work with pesticides $\mathrm{mg}$ of a.i./ $\mathrm{kg}$ of body weight is: $\mathrm{AAi}=0.2 ; \mathrm{AAd}=0.9$. To substantiate the AAi the ALV in the air of the working area $\left(1.5 \mathrm{mg} / \mathrm{m}^{3}\right)$ was used; to substantiatethe AAD the following indicators were used - the NOAEL for rats with reproductive (systemic) toxicity $(10 \mathrm{mg} / \mathrm{kg})$, maximum absorption of florpyrauxifen-benzyl through the skin (according to PPDB [6] - 11,4\%), calculated oral-dermal ratio $(8,8)$ and isoeffective NOAEL when applied to the skin $(88 \mathrm{mg} / \mathrm{kg})$, assurance coefficient (100).

According to the Guidelines 8.8.1.4-1622009 [21] and research results allowable inhalation exposure (AAi) and dermal (AAd) doses ( $\mathrm{mg}$ of a.i./ $\mathrm{kg}$ of body weight) that affect the people who have applied the herbicide during the work shift (6 hours) were calculated.

The results of a comparison of allowable exposure and approximate allowable doses indicated that the coefficients and indices of hazard (risk) of the complex effect of florpyrauxifen-benzyl on workers were below the permissible level. 


\section{ORIGINAL RESEARCH}

TOXICOLOGY OF PESTICIDES

\section{Conclusions}

1. Florpyrauxifen-benzyl and the Divixton EC drug are pesticides of the 3rd hazard category according to the limiting criterion of harmfulness - acute inhalation toxicity. Florpyrauxifen-benzyl is characterized by a general toxic effect on the body with predominant kidney damage.

According to the State sanitary rules 1.8.8.02.98, florpyrauxifen-benzyl is referred to the 4th hazard category as for mutagenic activity, as for carcinogenic and teratogenic activity, embryo and reproductive toxicity - to the 3rd hazard category.

To prevent the possibility of negative effects on human health and environmental quality and DAD and hygienic standards for florpyrauxifen-benzyl were proven:

DAD $-0.02 \mathrm{mg} / \mathrm{kg}$ of body weight/day.

MPL, mg kg: rice (grain) - 0,01 (QL by HPLC method - 0,005).

ALV in the air of the working area, $\mathrm{mg} / \mathrm{m}^{3}$ : 1.5 (QL by HPLC method - 0.07).

ALV in ambient air, $\mathrm{mg} / \mathrm{m}^{3}: 0.006$ (QL by HPLC method - 0.006).

Water basins MPC, $\mathrm{mg} / \mathrm{dm}^{3}: 0,001$, general sanitary (QL by HPLC method - 0,001$)$.

Soil APC, mg/kg: 0.14 (QL by HPLC method -0.05$)$.

If the existing rules for handling pesticide are obeyed the levels of florpyrauxifen- benzyl in the working environment, as well as of its external inhalation and dermal exposure are suffi- ciently safe for farm workers engaged in the application of herbicide Divixton EC. The sanitary protection zones established for the agroindustrial sector ensure safety of ground and aerial application of the drug for the population and objects of environment; in case of mechanized works on the cultivated areas, the production environment is safe in 3 days, the manual works renewal period is not required (rice processing technology does not provide for them).

Florpyrauxifen- benzyl is not found in rice crop. After application of the herbicide, there is no need to set the waiting period for rice grain harvest.

4. From the toxicological and sanitary point of view there is no objection to permanent registration in Ukraine of herbicide Divixton EC (a.i. - florpyrauxifen-benzyl, $25 \mathrm{~g} / \mathrm{l}$ ) for ground and aerial use in rice crops in the agricultural industry at a consumption rate 1.0$1.2 \mathrm{l} / \mathrm{ha}$, single or twofold application.

In order to ensure occupational safety and hygiene standards at drug application, it is necessary to fulfil the requirements of the developed "Guidelines for the safe use of herbicide Divixton EC".

When using herbicide Divixton EC for the protection of rice crops the control of agricultural raw materials, air of the working area, ambient air, water basins and soil should be carried out in accordance with the developed methods of chemical-analytical determination of florpyrauxifen-benzyl.

The autors declare that there are no conflicts of interest.

\section{REFERENCES}

1. Commission Implementing Regulation (EU) 2019/1138 of 3 July 2019 approving the active substance florpyrauxifenbenzyl in accordance with Regulation (EC) No 1107/2009 of the European Parliament and of the Council concerning the placing of plant protection products on the market, and amending the Annex to Commission Implementing Regulation (EU) No 540/2011 // Official Journal of the European Union. - 4.7.2019

2. Public release summary on the evaluation of the new active florpyrauxifen-benzyl (Rinskor ${ }^{\mathrm{TM}}$ ) in the product GF-3301 herbicide // Australian Pesticides and Veterinary Medicines Authority, 2018.

3. European Commission. - Commission Regulation 1107/2009. - Report and Proposed Decision prepared according to the European Commission Regulation (EU) № 1107/2009. - Florpyrauxifen benzyl (XDE-848 BE). Directorate General for Hygiene, Food Safety and Nutrition. Rapporteur Member State: Italy. Co- Rapporteur Member State: Austria. - April 2017.

4. U.S. Environmental Protection Agency Office of Pesticide Programs Registration Division (7505P) EPA Reg. Number: 62719-698, 2017.
5. Conclusion On Pesticides Peer Review.Peer review of the pesticide risk assessment of the active substance florpyrauxifen (variant assessed florpyrauxifen-benzyl) European Food Safety Authority (EFSA) // EFSA Journal 2018.

6. The Pesticide Properties Database (PPDB) developed by the Agriculture \& Environment Research Unit (AERU), University of Hertfordshire, funded by UK national sources and the EU - funded FOOTPRINT project. WWW dokument, 2018: https: // sitem. herts. ac. uk/ aeru/ ppdb/ en/ Reports/ 1663.htm.

7. EPA. - Florpyrauxifen-benzyl: New Active Ingredient, First Food Use. Human Health Risk Assessment for the Establishment of Permanent Tolerances on Rice, Fish, and Shellfish and Registration for Uses on Rice and Freshwater Aquatic Weed Control. - WWW dokument, 2018: https://www.regulations.gov.

8. USSR Ministry of Healthcare (1987) Metodicheskie ukazaniya po gigienicheskoy otsenke novykh pestitsidov: utv. MZ SSSR 13.03.87. - P. 4263-87 [Guidelines for sanitary assessment of new pesticides: USSR Ministry of Healthcare 13.03.1987.4 - P. 263-87], Kiyv. 


\section{ORIGINAL RESEARCH TOXICOLOGY OF PESTICIDES}

9. Ministry of Healthcare of Ukraine (1998) Ghighijenichna klasyfikacija pestycydiv za stupenem nebezpechnosti: DSanPiN 8.8.1.002-98 zatv. MOZ Ukrajiny 28.09.98. №2. [Hygiene classification of pesticides by hazard level (State sanitary rules 8.8.1.002-98: Ministry of Healthcare of Ukraine, 28.09.98. №2.)], Kyiv.

10. Guidelines on pesticide residue trials to provide datafor theregistration of pesticides and the establishment of maximum residue. FAO, UN. ROME. - 1986.

11. USSR Ministry of Healthcare (1980) Unifitsirovannye pravila otbora prob selskokhozyaystvennoy produktsii, produktov pitaniya i obektov okruzhayushchey sredy dlya opredeleniya mikrokolichestv pestitsidov: utv. Minzdrava SSSR 21.08.1979. - P. 2051-79. [Standardized rules for the sampling of agricultural and food products and environmental objects for the assessment of microdosed of pesticides: USSR Ministry of Healthcare, 21.08.1979. - P. 2051-79], Moskva: Minzdrav SSSR.

12. Ministry of ecology and natural resources of Ukraine (2019) Metodychni vkazivky z vyznachennja florpirauksyfen-benzylu u zerni rysu metodom vysokoefektyvnoji ridynnoji khromatoghrafiji: P. 1630-2019 vid 09.08.2019., zatv. Ministerstvom ekologhiji ta pryrodnykh resursiv Ukrajiny (Nakaz №293 vid 09.08.19) [Guidelines on determination of florpirauksyfen-benzyl in rice grain by high performance liquid chromatography method: P. 16302019 of 09.08 .2019 Ministry of ecology and natural resources of Ukraine (Directive № 293 of 09.08.19)].

13. USSR Ministry of Healthcare (1980) Metodicheskie ukazaniya $\mathrm{k}$ postanovke issledovaniy dlya obosnovaniya sanitarnykh standartov vrednykh veshchestv $\mathrm{v}$ vozdukhe rabochey zony: utv. MZ SSSR 04.04.80. - P. 2163-80 [Recommendations on the conduct of researches to justify the standards of hazardous substances in the air of working zone: USSR Ministry of Healthcare 04.04.80. - P. 216380], Moskva.

14. USSR Ministry of Healthcare (1985) Metodicheskie ukazaniya po ustanovleniyu orientirovochnykh bezopasnykh urovney vozdeystviya vrednykh veshchestv v vozdukhe rabochey zony: utv. MZ SSSR 04.11.85. - P. 400085 [Guidelines on determination of approximate safe levels of exposure to hazardous substances in the air of working zone: USSR Ministry of Healthcare 04.11.85. - P 4000-85], Moskva.

15. Ministry of Healthcare of Ukraine (2004) Metodychni vkazivky «Obgruntuvannja orijentovnykh bezpechnykh rivniv vplyvu (OBRV) khimichnykh rechovyn v atmosfernomu povitri naselenykh miscj», MV 2.2.6.-111-2004, zatv. MOZ Ukrajiny 07.10.04. - P. 485 [Guidelines on justification of approximate safe levels of exposure to chemical substances in the air of inhabited settlements, MV 2.2.6.-111-2004: Ministry of Healthcare of Ukraine, 07.10.04. - P. 485], Kyiv.

16. USSR Ministry of Healthcare (1976) Metodicheskie ukazaniya po razrabotke i nauchnomu obosnovaniyu predelno dopustimykh kontsentratsiy vrednykh veshchestv v vode vodoemov: utv. MZ SSSR 15.04.75. - P. 1296-75 [Guidelines for development and scientific justification of maximum allowable concentrations of hazardous substances in water basins: USSR Ministry of Healthcare, 15.04.75. - P. 1296-75], Moskva.

17. Guidelines for drinking-water quality.Second Edition. Geneva: WHO, 1993 - Vol. 1; 1996. - Vol. 2; 1997. - Vol. 3.

18. Ministry of ecology and natural resources of Ukraine (2019) Metodychni vkazivky z vyznachennja florpi- rauksyfen-benzylu u vodi metodom vysokoefektyvnoji ridynnoji khromatoghrafiji: P. 1632-2019 vid 09.08.2019., zatv. Ministerstvom ekologhiji ta pryrodnykh resursiv Ukrajiny (Nakaz №293 vid 09.08.19) [Guidelines for determination of florpirauksyfen-benzyl in water by high performance liquid chromatography method: P. 1632-2019 of 09.08.2019, Ministry of ecology and natural resources of Ukraine (Directive №293 of 09.08.19)].

19. USSR Ministry of Healthcare (1981) Vremennye metodicheskie ukazaniya po primeneniyu raschetnogo metoda obosnovaniya orientirovochnykh dopustimykh kontsentratsiy (ODK) pestitsidov $\mathrm{v}$ pochve. Utv. MZ SSSR 14.01.1981. - P. 2283-81 [Provisional recommendations on application of the method of calculation in justification of approximate allowable concentration of pesticides in soil: USSR Ministry of Healthcare, 14.01.1981. - P. 2283-81], Moskva: Minzdrav SSSR.

20. Ministry of ecology and natural resources of Ukraine (2019) Metodychni vkazivky z vyznachennja florpirauksyfen-benzylu u grunti metodom vysokoefektyvnoji ridynnoji khromatoghrafiji: P. 1629-2019 vid 09.08.2019., zatv. Ministerstvom ekologhiji ta pryrodnykh resursiv Ukrajiny (Nakaz №293 vid 09.08.19) [Guidelines for determination of florpirauksyfen-benzyl in soil by high performance liquid chromatography method: P. 1629-2019 of 09.08.2019, Ministry of ecology and natural resources of Ukraine (Directive №293 of 09.08.19)].

21. Serheiev S.G., Chayka Yu.G. (2008) Otsenka vozmozhnosti vozniknoveniya ostrykh toksicheskikh effektov pri rabote s pestitsidami s uchetom ikh izbiratelnosti deystviya [Assessment of the possibility of acute toxic effects while working with pesticides considering their selective nature].Modern problems of toxicology, №4. - P. 29-31.

22. Ministry of Healthcare of Ukraine (2009) Metodychni rekomendatsii «Vyvchennia, otsinka i zmenshennia ryzyku inhaliatsiinoho i perkutannoho vplyvu pestytsydiv na osib, yaki pratsiuiut $\mathrm{z}$ nymy abo mozhut zaznavaty vplyvu pid chas i pislia khimichnoho zakhystu roslyn ta inshykh obiektiv: MR 8.8.1.4-162-2009, zatv. MOZ Ukrainy 13.05.2009. №324 [Guidelines for studying, assessment and risk reduction of inhalation and percutaneous influence of pesticides on people who work with them and can be exposed to them during and after chemical treatment of plants and other objects: Ministry of Healthcare of Ukraine, 8.8.1.4-162-2009, of 13.05.2009. №324 ], Kyiv.

23. Ministry of ecology and natural resources of Ukraine (2019) Metodychni vkazivky z vyznachennia florpirauksyfen-benzylu $\mathrm{v}$ povitri robochoi zony ta atmosfernomu povitri metodom vysokoefektyvnoi ridynnoi khromatohrafii: P. 1631-2019 vid 09.08.2019., zatv. Ministerstvom ekolohii ta pryrodnykh resursiv Ukrainy (Nakaz №293 vid 09.08.19) [Guidelines for determination of florpirauksyfen-benzyl in the air of working zone by high performance liquid chromatography method: P. 16312019 of 09.08.2019, Ministry of ecology and natural resources of Ukraine (Directive №293 of 09.08.19)].

24. Guidance Document on Estimating Persistence and Degradation Kinetics from Environmental Fate Studies on Pesticides in EU Registration: report of the FOCUS Work Group on Degradation Kinetics, EC Document Reference Sanco/10058/2005 version 2.0. - 434 p.

25. Vasilev V.P., Dmitrenko P.A., Kavetskiy V.N. and others (1989) Spravochnik po kontrolyu za primeneniem sredstv khimizatsii v selskom khozyaystve [Handbook on control and application of chemization agents in agriculture], Kyiv (in Russian). 


\section{ORIGINAL RESEARCH TOXICOLOGY OF PESTICIDES}

\section{ОЦІНКА НЕБЕЗПЕЧНОСТІ, КОМПЛЕКСНЕ ГІГІЕНІЧНЕ НОРМУВАННЯ ФЛОРПІРАУКСИФЕН-БЕНЗИЛУ ТА ОБГРУНТУВАННЯ РЕГЛАМЕНТІВ БЕЗПЕЧНОГО ЗАСТОСУВАННЯ ГЕРБІЦИДУ НА ЙОГО ОСНОВІ ДЛЯ ЗАХИСТУ РИСУ}

О.П. Кравчук, С.Г. Сергеєв, В.І. Медведєв, А.П. Гринько, Н.В. Колонтаєва,

О.П. Васецька, О.М. Багацька, О.М. Кузнєцова, П.В. Алейнов

ДП «Науковий иентр превентивної токсикології, харчової та хімічної безпеки

імені академіка Л.І.Медведя Міністерства охорони здоров'я України», м. Київ, Україна

PЕЗЮМЕ. Флорпірауксифен-бензил - новий синтетичний селективний листяний гербіиид з групи піридинів з ауксиновим механізмом діi. Препарат Дівікстон, КЕ (д.р. - флорпірауксифен-бензил, 25 г/л) запропонований для захисту посівів рису від бур'янів.

Для державної реєстрації в сільському господарстві України та попередження можливості токсичного впливу на здоров'я людей і якість навколишнього середовища проведено оцінку небезпечності нового засобу захисту рослин, обгрунтовано критерії безпечності для здоров'я та середовища життєдіяльності людини. Обгрунтовано допустиму добову дозу флорпірауксифен-бензилу для людини на рівні 0,02 мг/кг; розроблено гігієнічні нормативи флорпірауксифен-бензилу у рисі, виробничому середовищі, повітрі, воді та грунті, критерії для контролю впливу на робітників, регламенти безпечного застосування гербіциду Дівікстон, КЕ в сільському господарстві.

Мета. Токсиколого-гігієнічна оцінка флорпірауксифен-бензилу та препарату Дівікстон, КЕ, обгрунтування критеріїв безпечності для здоров'я людей, оцінка можливості впливу на сільськогосподарських робітників та населення при наземному та авіаційному застосуванні препарату для захисту посівів рису.

Методи. Експертно-аналітичні, токсикологічні, фізико-хімічні, статистичні та гігієнічні.

Результати. На основі параметрів гострої токсичності за різних шляхів впливу, сенсибілізуючих властивостей та подразнюючої дії на слизові оболонки очей і шкіру флорпірауксифен-бензил і гербіцид Дівікстон, КЕ класифікуються як помірно небезпечні (3 клас). Віддалені ефекти дії (канцерогенність, мутагенність і тератогенність, токсичність для репродуктивної функції та розвитку) не є лімітуючими критеріями при оцінці небезпечності флорпірауксифен-бензилу. Затверджена в Україні ДДД флорпірауксифен-бензилу для людини - 0,02 мг/кг.

У результаті проведених польових випробувань в Україні встановлено, що величина професійного ризику за впливу флорпірауксифен-бензилу інгаляційним шляхом і через шкіру при наземному та авіаційному застосуванні не перевищувала допустимого рівня, санітарно-захисні зони забезпечують безпеку застосування гербіциду для населення та об'єктів довкілля; під час збирання врожаю в зерні рису та грунті рисового чеку залишки флорпірауксифен-бензилу не виявлені.

Висновок. Застосування гербіциду Дівікстон, КЕ для захисту рису у відповідності до сільськогосподарських та гігієнічних норм та регламентів не призведе до забруднення сільськогосподарської продукції та об'єктів навколишнього середовища та буде безпечним для населення та сільськогосподарських робітників.

Ключові слова: гербіцид, флорпірауксифен-бензил, токсичні властивості, оцінка небезпечності, гігієнічні нормативи та регламенти.

\section{ОЦЕНКА ОПАСНОСТИ, КОМПЛЕКСНОЕ ГИГИЕНИЧЕСКОЕ НОРМИРОВАНИЕ ФЛОРПИРАУКСИФЕН-БЕНЗИЛА И ОБОСНОВАНИЕ РЕГЛАМЕНТОВ БЕЗОПАСНОГО ПРИМЕНЕНИЯ ГЕРБИЦИДА НА ЕГО ОСНОВЕ ДЛЯ ЗАЩИТЫ РИСА} А.П. Кравчук, С.Г. Сергеев, В.И. Медведев, А.П. Гринько, Н.В. Колонтаева,

О.П. Васеикая. Е.Н. Багацкая, Е.М. Кузнецова, П.В. Алейнов

ГП «Научный центр превентивной токсикологии, пищевой и химической безопасности имени академика Л.И. Медведя Министерства здравоохранения Украины», г. Киев, Украина

PЕЗЮМЕ. Флорпирауксифен-бензил - новый синтетический селективный лиственный гербицид из группы пиридинов с ауксиновым механизмом действия. Препарат Дивикстон, КЭ (д.в. - флорпирауксифен-бензил, 25 г/л) предложен для защиты посевов риса от сорняков. Для государственной регистрации в сельском хозяйстве Украины и предупреждения возможности токсического воздействия на здоровье людей и качество окружающей среды проведена оценка опасности нового средства защиты растений, обоснованы критерии безопасности для здоровья и среды жизнедеятельности человека. Обоснована допустимая суточная доза флорпирауксифен-бензила для человека на уровне 0,02 мг/кг; разработаны гигиенические нормативы флорпирауксифен-бензила в рисе, производственной среде, воздухе, воде и почве, критерии для контроля воздействия на рабочих, регламенты безопасного применения гербицида Дивикстон, КЭ в сельском хозяйстве.

Цель. Токсиколого-гигиеническая оценка флорпирауксифен-бензила и препарата Дивикстон, КЭ, обоснование критериев безопасности для здоровья людей, оценка возможности воздействия на сельскохозяйственных рабочих и население при наземном и авиационном применении препарата для защиты посевов риса.

Методы. Экспертно-аналитические, токсикологические, физико-химические, статистические и гигиенические.

Результаты. На основе параметров острой токсичности при различных путях воздействия, сенсибилизирующих свойств и раздражающего действия на слизистые оболочки глаз и кожу флорпирауксифен-бензил и гербицид Дивикстон, КЭ классифицируются как умеренно опасные (3 класс). Отдаленные эффекты действия (канцерогенность, мутагенность и тератогенность, токсичность для репродуктивной функции и развития) не являются лимитируюшими критериями при оценке опасности флорпирауксифен-бензила.

В результате проведенных полевых испытаний в Украине установлено, что степень профессионального риска при воздействии флорпирауксифен-бензила ингаляционным путем и через кожу при наземном и авиационном применении не превышала допустимого уровня, санитарно-защитные зоны обеспечивают безопасность применения гербицида для населения и объектов окружающей среды; во время сбора урожая в зерне риса и почве рисового чека остатки флорпирауксифен-бензила не обнаружены. Выводы. Применение гербицида Дивикстон, КЭ для защиты риса в соответствии с сельскохозяйственными и гигиеническими нормами и регламентами не приведет к загрязнению сельскохозяйственной продукции и объектов окружающей среды и будет безопасным для населения и сельскохозяйственных рабочих.

Ключевые слова: гербицид, флорпирауксифен-бензил, токсические свойства, оценка опасности, гигиенические нормативы и регламенты.

Received 02/24/2020 